\title{
Measuring Nigerian Stakeholders' Perceptions of Auditor Independence: A Proposed Framework
}

\author{
Fatima Alfa Tahir ${ }^{1}$, Kamil M. D. Idris. ${ }^{1}$ \& Zaimah Zainol Ariffin. ${ }^{1}$ \\ ${ }^{1}$ School of Accountancy, College of Business, Universiti Utara Malaysia, Malaysia \\ Correspondence: Fatima Alfa Tahir, School of Accountancy, College of Business, Universiti Utara Malaysia, \\ Malaysia. E-mail: fadimaalfa@yahoo.com
}

Received: February 23, $2014 \quad$ Accepted: May 5, $2014 \quad$ Online Published: June 24, 2014
doi:10.5539/ass.v10n14p81

\begin{abstract}
The significance of the audit function stems from the need to enhance the credibility and reliability of financial reports by providing reasonable and objective assurance that the financial reports are indeed a reflection of the true state of affairs of a business concern. However, because an auditor's state of mind is difficult to observe, stakeholders of audit quality generally evaluate the auditor's appearance of objectivity by considering whether or not auditors are able to avoid circumstances that impair Audit Independence (AI). In this regard, most AI researches focus on examining factors influencing perceived audit independence (PAI) and not what actually constitutes PAI and how it can be measured. This paper proposes that PAI can be measured by assessing how auditors use safeguards to manage AI threats to acceptable levels that may no longer compromise AI. This in turn establishes the constituents of PAI and provides a basis for measuring AI.
\end{abstract}

Keywords: independence in appearance, threats, safeguards

\section{Introduction}

Auditor independence has and is still receiving much scholarly and regulatory attention in the wake of corporate collapses in both developing and developed countries. This is because auditors often provide or practice certain functions which may likely threaten their objectivity and cause users to doubt they are capable of rendering fair opinions. For example, the auditors of Enron received substantial audit and non-audit fees of up to $\$ 55$ million in 2001 which presented a self-interest threat that may have undermined the independence of the auditors to report fairly on a client they generated huge revenues from (Brown, 2005). Similarly, other failures resulted from familiarity threats that were engendered by auditors having personal affiliations or taking up appointments with their clients thereby hindering sufficient professional skepticism (Owen, 2003).

In Nigeria, AI compromise is also a serious challenge facing regulatory authorities, professional bodies and Government in Nigeria. In 2006 for example, Olatunde and Lauwo (2010) reported that Akintola Williams Deloitte was indicted for facilitating fraud and financial misstatements of Afribank Nigeria Plc and thereafter, conniving with the board of directors of Cadbury Nigeria Plc. in overstating the company's accounts to the tune of N15 billion (US\$111.11 million). Similarly, stakeholders and scholars have expressed much concern about how Nigerian auditors lobby for audit jobs thereby putting their independence on the line. Studies have also reported that professional bodies are not doing enough in sanctioning auditors that have been found wanting (Bakre, 2007; Olatunde \& Lauwo, 2010). In fact, the upsurge in shareholder associations and their involvement in decision making is another indication that shareholders are increasingly dissatisfied with the auditors' role in rendering fair and objective opinions (Okike, 2007). In other instances, auditors were reported to have certified financial statements as true and fair despite many defects and irregularities because of laxity in professional enforcement and minimal penalties. These issues have negative impact on public confidence in audited reports, investment and credit decisions which will result to costlier investments and hindrance to capital market efficiency (Al-Ajmi \& Saudagaran, 2011; Carmicheal, 1999; Shaub, 2004). In the light of these negative consequences, the need to further examine PAI in order to provide more insight into PAI and propose measures for enhancing AI policy frameworks becomes very important and necessary.

Most studies on PAI focus on examining the perceptions of auditors or other informed users on factor(s) influencing AI (e.g. Abu Bakar, Abdul Rahman, \& Abdul Rashid, 2005; Alleyne, Devonish, \& Alleyne, 2006; Irmawan, Hudaib, \& Haniffa, 2013). Others focus on individual factors such as non-audit service provision, 
audit market competition, audit committees, auditor tenure or audit fees (e.g. Geiger \& Rama, 2003; Hoitash \& Hoitash, 2009; Quick \&Warming-Rasmussen, 2009; Muhamad-Sori, Karbhari, \& Mohamad, 2010; Al-Thuneibat, Al-Issa \& Baker, 2011). There are a few studies on PAI in Nigeria and they generally focus on the factors influencing AI. For example, Adeyemi and Akinniyi (2011) found that large audit fees, NAS provision, lengthy tenures and audit firm size significantly influenced users' perception of AI. Another study by Adeyemi and Okpala (2011) examined the impact of AI on financial reporting by surveying auditors, shareholders, brokers, analysts, regulators, managers and lecturers and found that audit quality significantly influenced financial reporting. Adeyemi and Olowookere (2012) and Erah and Izedonmi (2012) investigated investors perception of NAS and AI and found that NAS significantly influenced perception of AI and called for regulatory supervision of auditors and imbibing a system that will continually assess auditors' standing with stakeholders in order to sustain public confidence in financial reports. Yet despite these studies, little scholarly attention has been paid to the constituents of independence in appearance or PAI. This study will defer from prior studies by examining the constituents of PAI based on stakeholders' assessments.

The paper is organized as follows. First an introduction on the background of AI issues is discussed which is followed by a discussion on the constituents of AI as provided by the IFAC regulatory framework. In particular, self-interest, self-review, familiarity, advocacy, intimidation threats and safeguards implementation are examined in the light of prior research efforts and synthesized in order to propose the measurement model. The model is premised on the legitimacy theory, hence the theory is discussed.

\section{Literature Review}

\subsection{Independence in Appearance}

Auditor independence (AI) does not necessitate an auditor to be free of all factors which may influence the ability to give unbiased opinions. It simply emphasizes freedom from factors which increase the likelihood of compromising audit opinions (McGrath, Siegel, Dunfee, Glazer, \& Jaenicke, 2001). AI has been categorized into two; Independence in fact which is the state of mind that allows an auditor to conduct an audit with objectivity, integrity and professional skepticism, and independence in appearance which relates to how informed users perceive the auditor. This paper focuses on independence in appearance because appearances of independence are both necessary and crucial in sustaining public confidence in auditors and audit reports (Alleyne, Devonish, \& Alleyne, 2006; Al-Ajmi \& Saudagaran, 2011). Abu Bakar, Abdul Rahman and Abdul Rashid (2005) also assert that auditors should not only be independent in fact, they also need to appear independent to financial statement users for their reports to be considered credible and reliable.

Even though the various regulatory frameworks have defined independence in appearance, few studies have actually examined the constituents of PAI or how PAI can be measured. Beattie and Fearnley (2002) reviewed the major regulatory frameworks on AI (IFAC, SOX, AICPA, ICAEW, AU, ICANZ) and concluded that they define independence in appearance as avoiding circumstances which may make informed users having knowledge of facts and the safeguards applied, to doubt the auditor's objectivity. Apart from AICPA which identifies seven major threats, all other frameworks require auditors to guard against five threatening circumstances; self-interest, self-review, familiarity, advocacy and intimidation threats. According to IFAC (2012), the bench mark for evaluation is what a reasonable informed user would conclude after weighing all relevant facts and safeguards applied. Based on this assertion, a PAI measure can be expected to constitute an assessment of the five major threats and safeguards implemented to eliminate or reduce the threats to acceptable levels that may no longer hamper objective and fair reporting. Few studies (e.g. Johnstone, Warfeild, \& Sutton, 2001; Shaub, 2004; Srivasta, Mock, \& Turner, 2009) have actually used the threat-safeguard approach to propose a measure for AI but have mostly not operationalized their frameworks. It is in this regard that this paper proposes to examine the constituents of AI using the threat-safeguard approach from the perspective of Nigerian stakeholders in order to provide a basis for measuring appearances of AI.

Independence in appearance has been defined as the avoidance of circumstances which can make a reasonable informed user, having all relevant knowledge including safeguards applied, to conclude that an auditor's objectivity, integrity and professional skepticism has been compromised (IFAC, 2012). In other words, auditor independence is threatened by various relationships and circumstances which should be avoided or managed at acceptable levels to assure objective reporting. IIA focuses on how informed users' perceive AI based on assessment of circumstances surrounding the conduct of the audit function such as employment relationships with client, material direct or indirect financial interest in client, contingent or unpaid fees, cumulative effect of many relationship, business relationship or cooperative arrangement with client, family relationship with client, litigation services for client or between client and auditor, assumption of management responsibilities or 
provision of non-audit services (NAS) that predispose the auditor to self-interest, self-review, familiarity, intimidation or advocacy threats that are significantly capable of influencing fair and objective reporting.

\subsection{Self-Interest Threats}

Prior studies show that many factors engender self-interest threat. According to IFAC $(2012 ; 200.4)$ self-interest threats result from circumstances which make the auditor have a stake or personal interest in the audit client. Such instances include having direct or indirect material financial interest in client, provision of non-audit services, economic dependence on client, loan to or from client, contingent fees or unpaid fees, business relations with client and prior or potential employment with client. According to Muhamad-Sori, Karbhari and Mohamad (2010) provision of both audit and NAS by incumbent auditors tilts auditors' allegiance to sustaining economic gains from additional services rather than resisting client pressure and upholding AI.

Similarly, Lowe and Pany (1996) show that material business relations influenced PAI. Furthermore, the revolving door practice between audit firms and their clients was generally found to be associated with higher discretionary accruals (Menon \& Williams, 2004), lower tendency to report violations (Kaplan \& Whitecotton, 2001) and inaccurate accounting estimates (Parlin \& Bartlett, 1994). Yet a few studies (Geiger \& North, 2006; Muhamad-Sori \& Mohamad, 2007) find no significant association between employment offers and auditor independence as proxied by discretionary accruals. Additionally, Trompeter (1994) finds that auditors are more likely to accept client accounting choices when they are compensated based on local office profitability suggesting that audit judgments can be influenced by financial incentives and interests. Beattie, Fearnley and Brandt (1999) and Alleyne, Devonish and Alleyne (2006) also show that unpaid audit or consulting fees threaten AI. This is because the auditor then becomes one of the client's creditors (Tribunella \& Tribunella, 2011) and a self-interest threat arises that could undermine objective reporting. Finally, (Dee, Lulseged, \& Nowlin, 2006; Sharma, Sharma, \& Ananthanarayanan, 2011) show that when auditors generate a large proportion of their income from any one client, there is an economic incentive to retain clients and economic rents accruing there from by compromising objectivity and audit quality.

In sum, when auditors are faced with self-interest threat, they are more likely to accept client management's choices and identify with their clients (Tribunella \& Tribunella, 2011; Alleyne, Devonish, \& Alleyne, 2006; Bamber \& Iyer, 2007), be reluctant in criticizing client management (Frankel, Johnson, \& Nelson, 2002; Muhamad-Sori, Karbhari, \& Mohamad, 2010), allow greater earnings management and discretionary accruals (Hoitash, Markelevich, \& Barragato, 2007) and are perceived negatively by stakeholders (Pany \& Reckers, 1983; Khurana \& Raman, 2006). This suggests that an alignment of auditor and client-management interests compromises auditor objectivity and leads to a decline in perceived independence and audit quality. In line with this thinking, the study proposes that when stakeholders evaluate AI, they are likely to assess the existence of self-interest threats that may influence objective reporting, hence:

Proposition 1: PAI measure should embody an assessment of self-interest threats

\subsection{Self-review Threat}

Self-review threats emanate from circumstances which place the auditor in a position to review their own work (e.g. by providing joint assurance and certain non-audit services) or were former client employees (IFAC, 2012; 200.5). For example, Pany and Reckers (1983) find directors perceived system design a great threat to AI. Bartlett (1993) examined CPA and bankers perceptions of AI in ten conflict circumstances; size of audit fee, provision of management consulting services which entailed design and implementation of accounting system, executive search assistance, hiring of chief financial officer and assistance in complex accounting transactions, contingent fees, joint venture with client, budget pressures and attest services only. Findings have shown that there were significant differences in perceptions between bankers and CPA's in nine cases and bankers perceived greater impairment of $\mathrm{AI}$ in the services provided while auditors were overly confident in their ability to be independent while providing additional services. Similarly, Quick and Warming-Rasmussen (2009) found that German academic investment club members perceived an impairment of AI when auditors jointly provided audit and most NAS especially human resource services. Yet Muhamad-Sori, Karbhari and Mohamad (2010) report that the threat of AI impairment from joint provision in Malaysia was reduced when separate department of the audit firm rather than audit department provided NAS and also when NAS provision was strictly limited to non-audit clients. Additionally, Kumar, Shanmugam and Zakariya (2008) show shareholders of Malaysian Government linked companies' perceived greater risk of AI impairment from management functions compared to human resource services and other advisory services.

In sum, the studies show that auditors' facing the self-review threat by providing certain NAS were perceived as less independent (Firth, 1981; Shockley, 1981; Lowe, Geiger, \& Pany, 1999; Shaub, 2004; Cheung \& Hay, 2004) 
and exerted little effort in auditing their prior work (Quick \& Warming-Rasmussen, 2009). Also, the fact that effective audit committees were unlikely to procure NAS from incumbent auditor (Abbott, Parker, Peters, \& Raghunandan, 2003), or outsource internal audit services to incumbent auditors (Swanger \& Chewning, 2001; Abbott, Parker, Peters, \& Rama, 2007) indicates there is a negative perception when auditors provided services which they also reviewed. Since self-review is negatively perceived, stakeholders are more likely to examine whether auditors were placed in position to review their own work when measuring AI. It is therefore reasonable to propose that:

Proposition 2: PAI measure should embody an assessment of self-review threats

\subsection{Advocacy Threat}

Advocacy threat arises when auditors are placed in circumstances that promote, or appear to promote client management interests. The IFAC (2012: 200.6) provides that circumstances giving rise to advocacy threat include promoting securities of client, rendering certain NAS as litigation or dispute resolution with third parties or representing the client before tax authorities. Empirical studies on advocacy threats suggest a negative impact on AI. For example, Crain, Goldwasser, and Harry (1994) assert that litigation support services are prone to malpractice claims and threaten public accounting practice. Trompeter (1994) and Brody and Masseli (1996) show that auditors are conservative and act in their clients' interests in order to enhance their own economic interests in instances where accounting regulations are ambiguous. However, Haynes, Jenkins and Nutt (1998) examined the claim that auditors advocated their client management's position using an experimental study of 96 certified public accountants. Findings indicate auditors do not automatically advocate for their clients in situational or contextual conditions where client position was not known. They only supported their client position (whether in buyer or seller situations) when specific information about client preferences was provided, though this was more associated with experienced auditors.

Ponemon (1995) also found that professional accountants providing litigation support services judgments were more likely to incline with their client's as experience and ethical reasoning was not found to influence objectivity. The biasness of accounting estimates made by auditors indicated auditors' tendency to subordinate their judgment in favor of their client management. Even though the AICPA does not recognizes tax services as violating AI, Francis (2006) argues that aggressive tax planning by accounting firms which has resulted in issuance of tax planning guidelines suggests that firms pursue their client management interests of reducing or avoiding taxes. Additionally, Jenkins and Lowe (2011) investigated the perceptions of 58 auditors through a mail survey to determine perceptions of their responsibilities to client management and the extent to which they would advocate for their clients. The results showed $32.8 \%$ of auditors supported client advocacy, $65.5 \%$ were supportive of client accounting choices and $63.8 \%$ were sensitive to pursuing their economic interests as client loss was an important consideration. Similarly, Cheung and Hay (2004) investigated the perception of New Zealand shareholders on auditor independence and found shareholders perceived independence to be compromised when auditors provided internal audit services, IT systems design, advocated for their clients in takeover bids, Managed client buildings or became directors in client company.

Put together, these studies indicate that auditors providing litigation support services were more likely to advocate their client position (Crain, Goldwasser, \& Harry, 1994; Trompeter, 1994; Ponemon, 1995; Brody \& Masselli, 1996; Haynes, Jenkins, \& Nutt, 1998) assist their clients in aggressive tax planning and representation before Tax authorities (Shaub, 2004; Francis, 2006), view themselves as client advocates and responsible to management (Jenkins \& Lowe, 2011) while users perceived objectivity as impaired when auditors advocated client management position (Cheung \& Hay, 2004). Hence, the studies suggest that auditors are perceived as biased when they advocate client positions. Since stakeholders view client advocacy as threatening auditor objectivity, they are more likely to consider and assess circumstances that place auditors in advocacy position when assessing AI. In this regard, the study makes the following proposition:

Proposition 3: PAI measure should embody an assessment of advocacy threats

\subsection{Familiarity Threats}

According to IFAC $(2012,200.7)$ familiarity threats result from circumstances as having close family ties with client employees, family members occupying influential position in client company, influential client officer was formerly a partner, lengthy audit tenures or acceptance of gift and hospitality from client. Koh and Mahathevan (1993) investigated middle managers perceptions of auditor client employment and AI as they related to past and future audits. Results show there were greater independence concerns when time period between audit conclusion and employment acceptance was short. There were similar concerns for future audits only when the former auditor held a supervisory role in the audit firm or assumed an influential accounting position in the client 
firm. Similarly, Law (2010) surveyed 205 CPA's and interviewed 20 others to investigate perceptions of CPA's employment with former clients influence on auditor independence post Enron. Their findings indicate the rank of partner significantly influences perceptions of independence. Furthermore, independence was perceived to be compromised when former auditor had direct relationship with client, but more severely compromised when a former manager was involved. Beasley, Carcello and Hermanson (1999) and Lennox (2005) also report that the presence of alumni increases auditor unwillingness to question former colleagues and exercise sufficient professional skepticism due to implied trust and confidence on alumni colleague.

Lengthy audit engagements also present familiarity threat which may compromise auditor objectivity because of the closeness that develops between auditor and client management. For instance, Davis, Soo and Trompeter (2002) find a significant positive relationship between audit tenure and forecast errors. Al-Thuneibat, Al-Issa and Baker (2011) also find a positive relation between audit tenure and equity risk premium, equity risk premium increasing as audit firm tenure increases resulting in reduced audit quality. Yet other studies show lengthy tenures are perceived as enhancing auditor independence and audit quality (Ghosh \& Moon, 2005; Lim \& Tan, 2010). Also, Pany and Reckers (1980) investigated the impact of gifts, discount arrangements and client size on stockholders perceptions of AI. Results indicate that though there were no differences between discounts and gifts, there were differences at specific levels of savings which was statistically significant at $\$ 40$ and $\$ 125$ where subjects were not inclined to agree and uncertain in most instances. However, Law (2010) found that in Hong Kong, some level of social-relations between auditor and clients as 'guanxi' relations may not impair AI.

Put together, the studies suggest that when auditors become excessively familiar with their clients, they are more likely to trust client accounting choices and identify with their interest (Beasley, Carcello, \& Hermanson, 1999; Bamber \& Iyer, 2007), reduce level of professional skepticism by exerting little effort in audit planning and testing (Nelson, 2009) and also more likely to be perceived by users as biased (Pany \& Reckers, 1980; Law, 2010). Additionally, close bonds resulting from lengthy tenures were found to be associated with lower audit quality in terms of higher discretionary accruals and earnings management (Dopuch, King, \& Schwartz, 2001; Davis, Soo \& Trompeter, 2009) and higher equity risk premium demands (Al-Thuneibat, Al-Issa, \& Baker, 2011). Furthermore, users perceive auditor acceptance of client gifts and hospitality as compromising auditor objectivity (Pany \& Reckers, 1980; Law, 2010). The results suggest that circumstances engendering familiarity threat are perceived by stakeholders as negatively impacting auditor independence. Hence informed users will be more likely to evaluate familiarity threats when evaluating AI. It is therefore reasonable to suggest that:

Proposition 4: PAI measure should embody an assessment of familiarity threats

\subsection{Intimidation Threats}

According to IFAC $(2012 ; 200.8)$ Intimidation threats emanate from threatened auditor dismissal, threatened litigation, client pressure to reduce extent of audit work to reduce fees, greater client expertise in matters or partner promotion depending on acceptance of client policies. Studies have suggested that clients often exert pressure on auditors to influence the type and form of audit opinion. For instance, Knapp (1985) found loan officers perceived ambiguity in technical standards to reduce auditor's ability to withstand client pressure while healthier clients were perceived to have a higher likelihood of influencing auditor judgments. Similarly, Bierstaker and Wright (2001) report that auditors responded to fee pressures by reducing budgeted hours, hence increasing efficiency while partner pressures were met by limiting planned tests. Fearnley, Beattie and Brandt (2005) use a qualitative study to show that intimidation and familiarity threats were the most frequently encountered in auditor-client associations. Other studies (e.g. Knapp, 1985; Chung \& Kallapur, 2003) indicate auditors are more likely to acquiesce to larger clients in strong financial condition than smaller and weaker ones.

In sum, the studies indicate a client's ability to exert pressure on auditor judgment is associated with its financial condition while auditors facing intimidation threats were more likely to be pressured into hasty decisions and bullied into accepting client choices (Fearnley, Beattie, \& Brandt, 2005) or threatened with fee reduction or change (Alleyne, Devonish, \& Alleyne, 2006; Al-Ajmi \& Saudagaran, 2011). The risk of client loss has been found to be significantly associated with independence compromises (Falk, Lynn, Mestelman, \& Shehata, 2000) as auditors succumb to pressure to retain clients. Shaub (2004) and Behn, Carcello, Hermanson and Hermanson, (1997) argue that auditors earning significant tax fees also face an intimidation threat and audit managers are often less willing to confront client when compensation schemes are tied to client satisfaction which has been found to decline with greater professional skepticism. Consistent with these studies, stakeholders may likely perceive a possible impairment of AI due to perceived intimidation where auditors have large influential clients, provide tax services, are faced with likely switch or compensated based on client retention. Hence, the study makes the following proposition: 
Proposition 5: PAI measure should embody an assessment of intimidation threats

\subsection{Safeguards Implementation}

According to IFAC $(2012,100.13)$, safeguards are measures, actions or procedures that may be employed to eliminate or reduce threats to acceptable levels that no longer threaten auditor objectivity. These generally fall under professional, legislative or regulatory safeguards or safeguards within the work environment. In applying the safeguards, Sec (200.10) requires the professional accountant to exercise professional judgment on the best way to manage threats or otherwise, decline or terminate engagement. The benchmark for exercising professional judgment is considering what a reasonable and informed third party will conclude after weighing all relevant facts and circumstances available to the professional accountant such as the significance of the threat, nature of engagement and firm structure. Examples include firm quality control procedures, disclosure of fees (NAS and attest) and types of services provided, disciplinary measures, professional and regulatory monitoring, separation of attest and consulting staff, existence of corporate governance mechanisms, independent partner reviews and partner or firm rotation.

Prior studies show that safeguards enhance AI by eliminating or reducing threats to levels that they may no longer undermine AI. For instance, Muhamad-Sori, Karbhari and Mohamad (2010) found that senior managers, loan officers and auditors in Malaysia perceived a significant threat from joint provision of attest and consulting services. This threat was however perceived to be effectively mitigated when safeguards such as separation of attest from consulting staff was in place. Similarly, Hoitash and Hoitash (2009) found that strong audit committees were associated with a higher level of assurance, appointment of high quality auditors and lower likelihood of dismissal. Abbott, Parker, Peters and Raghunandan (2003) also report lower NAS fee ratios for companies having independent audit committees that met quarterly, suggesting that the oversight function of audit committees in safeguarding PAI and improving reporting quality will result in lower usage of incumbent auditor for NAS provision. With regards to rotation, Meyer, Rigsby and Boon (2006) find that the strength of auditor client relationships raise possibilities of the removal of a qualified opinion suggesting that audit-client relations influenced auditor decisions requiring more judgments (materiality and uncertainty) compared to litigation risks whereas Al-Thuneibat, Al-Issa and Baker (2011) showed auditor rotation was an important safeguard as lengthy tenures were associated with lower perceptions of audit quality and increased risk on equity. Additionally, Johnstone, Warfield and Sutton (2001) report that corporate governance mechanisms, audit firm culture and policies, regulatory oversight and quality controls are effective safeguards that mitigate independence risks while Bedard, Deis, Curtis and Jenkins (2008) report that safeguards are generally perceived as important in enhancing audit quality.

Taken together, the regulatory frameworks and empirical results suggest implementing adequate safeguards is necessary in order to mitigate the threats that characterize the auditor-client relationships by eliminating or managing threats to acceptable levels that may no longer compromise AI. Thus, the more auditors are perceived as independent, the greater the likelihood their opinions will be considered a fair representation by stakeholders. In this regards, stakeholders are likely to assess the safeguards implemented by auditors when assessing appearances of AI. Thus, it is reasonable to suggest that:

Proposition 6: PAI measure should embody an assessment of safeguards implementation 


\section{Proposed Research Framework}

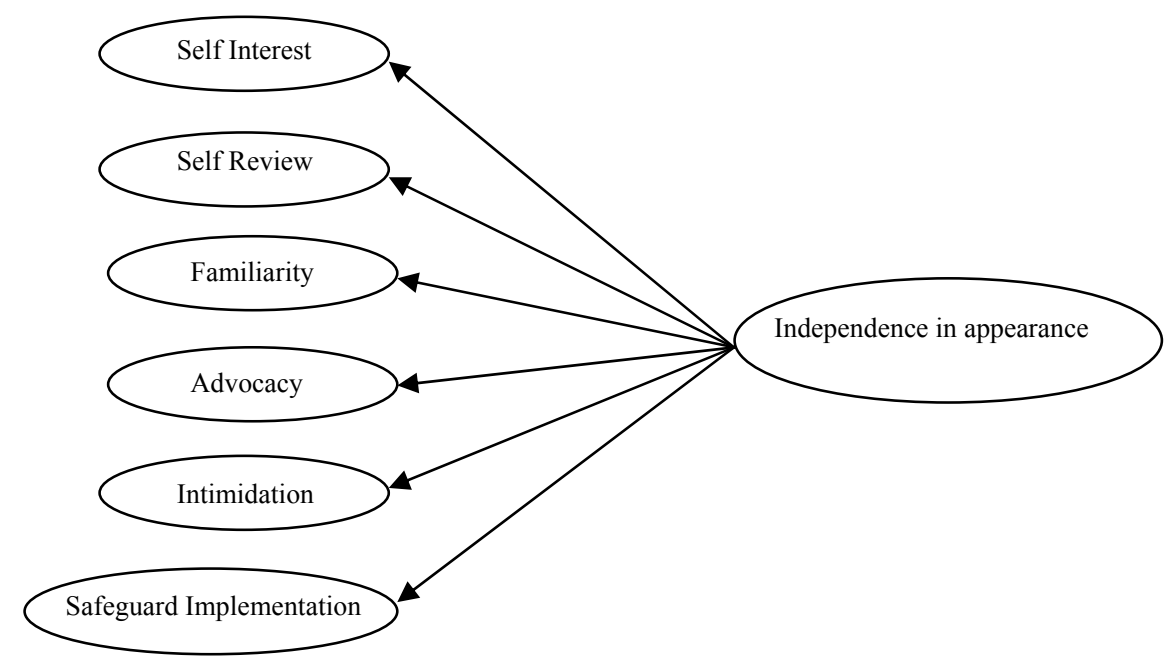

Figure 1. Proposed research framework

The proposed conceptual framework is based on the threat-safeguards approach and shows that independence in appearance can be measured by an assessment of the self-interest, self-review, familiarity, advocacy, intimidation and safeguards implemented to mitigate these threats. It is therefore postulated that PAI should embody an assessment of these threats and the safeguards implemented which reduces the threats to acceptable levels that may not undermine auditor objectivity.

\section{Underpinning Theory}

\subsection{Legitimacy Theory}

The legitimacy theory is based on the premise that organizations need to affirm their legitimacy within the environment by conforming to societal norms and expectations in order to remain relevant and continue to exist (Suchman, 1995). As societies' attitude and expectations change, organizations need to adapt to changing requirements to ensure activities are legitimate and justified (Deegan, 2006). The Legitimacy of an entity is an operational resource that is obtained competitively from the environment and used to achieve stated objectives (Pfeffer \& Salancik, 2003; Suchman, 1995). In this regard, organizations obtain this resource by tailoring their objectives and activities in line with societal expectations, values and norms. Deegan, (2009) argues that when the entity is perceived to deviate from the social contract, the contract is rescinded and penalties including legal restrictions on operations, limiting supply of material and labor resources or reducing product demand through consumer boycotts may be imposed. Additionally, as societies evolve, their attitudes and expectations change. Therefore entities need to adapt to these changing requirements to support the legitimacy of their activities and continuous operations (Deegan, 2006). According to Lindblom (1994), societal expectations may sometimes defer from organizational performance and a gap results which signifies wrong perceptions or organizational lapses. In such situations, Lindblom, (1994) argues that the organization needs to reinforce its operational legitimacy by finding congruence between societal stakeholder expectations and its own objectives. Borrowing from Dowling and Pfeffer (1975), Lindblom (1994) suggests that the threat of a legitimacy gap can be mitigated by strategies as communicating and demonstrating appropriateness of organizational activities to societal expectations, educating the various stakeholders on activity changes in line with environmental value systems, influencing and/or manipulating stakeholder perceptions on organizational activities or trying to change societal expectations to focus on possible goal attainability.

With respect to auditor independence, though the legal framework provides the legitimacy for the audit function itself, the loss in public confidence resulting from audit failures necessitates the need to re-establish the legitimacy of the profession. The environment of the auditor includes various stakeholders such as informed users, regulators and professional bodies. In line with the legitimacy theory, all stakeholders have expectations of an independent audit report on financial statements that is true and fair to make informed decisions. As independence in appearance (PAI) depends on how informed users perceive existing threats and safeguards applied to mitigate these threats to acceptable levels, stakeholders will periodically examine whether or not 
auditors manage these threats to acceptable levels to ascertain their legitimacy. In fact one of the outcomes of this assessment is the audit expectation gap which results from the gap between public expectation and actual audit capabilities. Afrem (2012) affirms that the perception of stakeholders about the auditor's objectivity becomes very significant because positive perceptions of independence add legitimacy to not only the auditor but also to audit function and financial statements as a whole. Where stakeholders have negative perception with regards to the threats and safeguards applied or auditors are perceived to deviate from their role, stakeholders impose regulatory restrictions and penalties. For instance, in order to restore public confidence in the auditing profession after the corporate collapses and audit failures, re-establishment efforts such as requirement for increased transparency, increased regulatory supervision and review of standards (Power, 2003) were pursued. In line with this, the legitimacy theory provides the basis for stakeholders to evaluate the appearance of independence (PAI) by considering whether auditors avoid or manage threats to acceptable levels by implementation of safeguards.

\section{Conclusion, Contributions and Policy Implications}

This paper proposes that independence in appearance (PAI) can be measured by evaluating the impact of safeguards implemented on the threats which may undermine auditor objectivity (self-interest, self-review, familiarity, advocacy and intimidation). If validated, the framework will empirically provide important insight to regulators, professional bodies and other stakeholders into measuring AI. A PAI measure will also contribute significantly to the body of knowledge from both academic and methodological perspectives. Academically, the proposed PAI measure will provide a basis for examining stakeholders' perceptions of AI which has only been studied mainly from an exploratory perspective of factors influencing PAI (See Beattie, Fearnley, \& Brandt, 1999; Alleyne, Devonish, \& Alleyne, 2006; Al-Ajmi \& Saudagaran, 2011; Irmawan, Hudaib, \& Haniffa, 2013). Secondly, a PAI measure is also a methodological contribution to knowledge because presently there is no measure for evaluating the dimension of independence in appearance. This is also in line with prior studies such as Parasuraman, Zeithaml and Berry (1985) that have proposed and developed measures.

Thirdly, the study is also expected to contribute to the Nigerian regulatory framework by providing a better understanding of how Nigerian stakeholders' perceive auditor independence which could also be applicable to other developing countries having similar socio-economic and cultural environments. Additionally, the results are also expected to inform regulators such as the Financial Reporting Council and professional accounting bodies such as the Institute of Chartered Accountants of Nigeria and Association of National Accountants of Nigeria and Policy makers on how AI frameworks and standards can be structured to enhance capital market efficiency. Furthermore, the proposed PAI measure is also expected to provide regulators (e.g. FRCN) and professional accountancy bodies in Nigeria (ICAN and ANAN) with a means of measuring and monitoring PAI which will inform the structure and level of regulatory response/policies to high or low levels of PAI. As the presence of professional codes alone does not ensure compliance, regulatory bodies need a consistent mechanism of monitoring perceptions of AI because perceptions have a significant influence on credibility of financial reports. This will also provide empirical evidence to guide AI standards and policies (DeFond \& Francis, 2005). The PAI measure will also open up avenues for further research as other researchers may wish to validate and test it in various settings using various samples for further improvements.

\section{References}

Abbott, L. J., Parker, S., Peters, G. F., \& Raghunandan, K. (2003). An Empirical Investigation of Audit Fees, Non-audit Fees, and Audit Committees. Contemporary Accounting Research, 20(2), 215-234. http://dx.doi. org/10.1506/8YP9-P27G-5NW5-DJKK

Abbott, L. J., Parker, S., Peters, G. F., \& Rama, D. V. (2007). Corporate governance, audit quality, and the Sarbanes-Oxley Act: Evidence from internal audit outsourcing. The Accounting Review, 82(4), 803-835. http://dx.doi.org/10.2308/accr.2007.82.4.803

Abu Bakar, N. B., Abdul Rahman, R. A., \& Abdul Rashid, H. M. (2005). Factors influencing auditor independence: Malaysian loan officers' perceptions. Managerial Auditing Journal, 20(8), 804-822. http://dx. doi.org/10.1108/02686900510619665

Adeyemi, S. B., \& Akinniyi, K. O. (2011). Stakeholders' perception of the independence of statutory auditors in Nigeria. Serbian Journal of Management, 6(2), 247-267. http://dx.doi.org/10.5937/sjm1102247A

Adeyemi, S. B., \& Okpala, O. (2011). The impact of audit independence on financial reporting: Evidence from Nigeria. Business and Management Review, 1(4), 9-25.

Adeyemi, S. B., \& Olowookere, J. K. (2012). Non-Audit Services and Auditor Independence-Investors' 
Perspective in Nigeria. Business \& Management Review, 2(5).

Afrem, R. (2012). Does the European Commission require more independence than investors? A study of replies made to the Green Paper. (Unpublished Doctoral dissertation, Jonkoping University, Sweden).

Al-Ajmi, J., \& Saudagaran, S. (2011). Perceptions of auditors and financial statement users regarding auditor independence in Bahrain. Managerial Auditing Journal, 26(2), 130-160.

Alleyne, P. A., Devonish, D., \& Alleyne, P. (2006). Perceptions of auditor independence in Barbados. Managerial auditing journal, 21(6), 621-635. http://dx.doi.org/10.1108/02686900610674898

Al-Thuneibat, A. A., Al Issa, R. T. I., \& Baker, R. A. A. (2011). Do audit tenure and firm size contribute to audit quality? Empirical evidence from Jordan. Managerial Auditing Journal, 26(4), 317-334. http://dx.doi.org/ $10.1108 / 02686901111124648$

Bamber, E. M., \& Iyer, V. M. (2007). Auditors' identification with their clients and its effect on auditors' objectivity. Auditing: A Journal of Practice \& Theory, 26(2), 1-24. http://dx.doi.org/10.2308/aud.2007. 26.2.1

Bartlett, R. W. (1993). A scale of perceived independence: New evidence on an old concept. Accounting, Auditing \& Accountability Journal, 6(2), 52-67. http://dx.doi.org/10.1108/09513579310036378

Beasley, M. S., Carcello, J. V., \& Hermanson, D. R. (1999). Fraudulent Financial Reporting: 1987-1997. An Analysis of US Public Companies. The Auditor's Report, 22(3), 15-17.

Beattie, V., \& Fearnley, S. (2002). Auditor independence and non-audit services: A literature review. Institute of Chartered Accountants in England and Wales, London.

Beattie, V., Brandt, R., \& Fearnley, S. (1999). Perceptions of auditor independence: UK evidence. Journal of International Accounting, Auditing and Taxation, 8(1), 67-107. http://dx.doi.org/10.1016/S1061-9518 (99)00005-1

Bedard, J. C., Deis, D. R., Curtis, M. B., \& Jenkins, J. G. (2008). Risk monitoring and control in audit firms: A research synthesis. Auditing: A Journal of Practice \& Theory, 27(1), 187-218. http://dx.doi.org/10.2308/aud. 2008.27.1.187

Behn, B. K., Carcello, J. V., Hermanson, D. R., \& Hermanson, R. H. (1999). Client Satisfaction and Big 6 Audit Fees. Contemporary Accounting Research, 16(4), 587-608. http://dx.doi.org/10.1111/j.1911-3846.1999. tb00597.x

Bierstaker, J. L., \& Wright, A. (2001). The effects of fee pressure and partner pressure on audit planning decisions. Advances in Accounting, 18, 25-46. http://dx.doi.org/10.1016/S0882-6110(01)18004-1

Brody, R. G., \& Masselli, J. J. (1996). Tax preparers: Whose team are they on? The National Public Accountant, $41(3), 18-20$.

Brown, R. E. (2005). Enron/Andersen: Crisis in us accounting and lessons for government. Public Budgeting \& Finance, 25(3), 20-32. http://dx.doi.org/10.1111/j.1540-5850.2005.00365.x

Carmichael, D. R. (1999). In Search of Concepts of Auditor Independence. CPA Journal, 69(5), 38-43.

Cheung, J., \& Hay, D. (2004). Auditor independence: The voice of shareholders. University of Auckland Business Review, 6(2), 67-75.

Chung, H., \& Kallapur, S. (2003). Client importance, non-audit services, and abnormal accrual. The Accounting Review, 78(4), 931-955. http://dx.doi.org/10.2308/accr.2003.78.4.931

Crain, M., Goldwasser, D., \& Harry, E. (1994). Expert witnesses-in jeopardy? Journal of Accountancy, 178(6), 42-48.

Davis, L. R., Soo, B. S., \& Trompeter, G. M. (2009). Auditor tenure and the ability to meet or beat earnings forecasts. Contemporary Accounting Research, 26(2), 517-548. http://dx.doi.org/10.1506/car.26.2.8

Davis, L. R., Soo, B., \& Trompeter, G. (2002). Auditor tenure, auditor independence and earnings management. Working paper, Boston College, Chestnut Hill, MA.

Dee, C. C., Lulseged, A., \& Nowlin, T. S. (2006). Prominent audit clients and the relation between discretionary accruals and non-audit service fees. Advances in Accounting, 22, 123-148. http://dx.doi.org/10.1016/S08826110(06)22006-6

Deegan, C. (2006). Legitimacy theory. In Z. Hoque (Ed.), Methodological issues in Accounting Research: 
Theories and methods (pp. 161-181). Spiramus Press, London.

Deegan, C. (2009). Financial Accounting Theory (3rd ed.). Sydney: McGraw Hill.

DeFond, M. L., \& Francis, J. R. (2005). Audit research after Sarbanes-Oxley. Auditing: A Journal of Practice \& Theory, 24(s-1), 5-30.

Dopuch, N., King, R. R., \& Schwartz, R. (2003). Independence in Appearance and in Fact: An Experimental Investigation. Contemporary Accounting Research, 20(1), 79-114. http://dx.doi.org/10.1506/9B5D-HLLPBBQE-8N3F

Erah, D. O., \& Izedonmi, F. (2012). Non audit services and auditor's independence in Nigeria. International Journal of Business and Management Tomorrow, 2(7), 1-8.

Falk, H., Lynn, B., Mestelman, S., \& Shehata, M. (2000). Auditor independence, self-interested behavior and ethics: Some experimental evidence. Journal of Accounting and Public Policy, 18(4), 395-428.

Fearnley, S., Beattie, V. A., \& Brandt, R. (2005). Auditor independence and audit risk: A reconceptualization. Journal of International Accounting Research, 4(1), 39-71. http://dx.doi.org/10.2308/jiar.2005.4.1.39

Firth, M. (1981). Auditor-client relationships and their impact on bankers' perceived lending decisions. Accounting and Business Research, 11(43), 179-188. http://dx.doi.org/10.1080/00014788.1981.9729699

Francis, J. R. (2006). Are Auditors Compromised by Non-audit Services? Assessing the evidence. Contemporary Accounting Research, 23(3), 747-760. http://dx.doi.org/10.1506/4VD9-AE3K-XV7L-XT07

Frankel, R. M., Johnson, M. F., \& Nelson, K. K. (2002). The relation between auditors' fees for non-audit services and earnings management. The Accounting Review, 77(s-1), 71-105. http://dx.doi.org/10.2308/accr. 2002.77.s-1.71

Geiger, M. A., \& North, D. S. (2006). Does hiring a new CFO change things? An investigation of changes in discretionary accruals. The Accounting Review, 81(4), 781-809. http://dx.doi.org/10.2308/accr.2006.81. 4.781

Geiger, M. A., \& Rama, D. V. (2003). Audit fees, non-audit fees and auditor reporting on stressed companies. Auditing: A Journal of Practice \& Theory, 22(2), 53-69. http://dx.doi.org/10.2308/aud.2003.22.2.53

Ghosh, A., \& Moon, D. (2005). Auditor tenure and perceptions of audit quality. The Accounting Review, 80(2), 585-612. http://dx.doi.org/10.2308/accr.2005.80.2.585

Haynes, C., Jenkins, J., \& Nutt, S. (1998). The relationship between client advocacy and audit experience: An exploratory analysis. Auditing: A Journal of Practice \& Theory, 17(2), 88-104.

Hoitash, R., \& Hoitash, U. (2009). The role of audit committees in managing relationships with external auditors after SOX: Evidence from the USA. Managerial Auditing Journal, 24(4), 368-397. http://dx.doi.org/10. 1108/02686900910948206

Hoitash, R., Markelevich, A., \& Barragato, C. A. (2007). Auditor fees and audit quality. Managerial Auditing Journal, 22(8), 761-786. http://dx.doi.org/10.1108/02686900710819634

IFAC. (2012). Code of Ethics for Professional Accountants (New York: IFAC). Retrieved from http://www.ifac.org/ethics

Irmawan, Y., Hudaib, M., \& Haniffa, R. (2013). Exploring Perceptions of Auditor Independence in Indonesia. Journal of Islamic Accounting and Business Research, 4(2), 4. http://dx.doi.org/10.1108/JIABR-09-20120061

Jenkins, J. G., \& Lowe, D. J. (2011). Auditors as advocates for their clients: Perceptions of the auditor-client relationship. Journal of Applied Business Research (JABR), 15(2), 73-78.

Johnstone, K. M., Warfield, T. D., \& Sutton, M. H. (2001). Antecedents and consequences of independence risk: Framework for analysis. Accounting Horizons, 15(1), 1-18. http://dx.doi.org/10.2308/acch.2001.15.1.1

Kaplan, S. E., \& Whitecotton, S. M. (2001). An examination of auditors' reporting intentions when another auditor is offered client employment. Auditing: A Journal of Practice \& Theory, 20(1), 45-63. http://dx.doi. org/10.2308/aud.2001.20.1.45

Khurana, I. K., \& Raman, K. K. (2006). Do investors care about the auditor's economic dependence on the client? Contemporary Accounting Research, 23(4), 977-1016. http://dx.doi.org/10.1506/D171-8534-4458-K037

Knapp, M. C. (1985). Audit conflict: An empirical study of the perceived ability of auditors to resist management 
pressure. The Accounting Review, 16(2), 202-211.

Koh, H. C., \& Mahathevan, P. (1993). The effects of client employment on auditor independence. The British Accounting Review, 25(3), 227-242. http://dx.doi.org/10.1006/bare.1993.1023

Kumar, M., Shanmugam, M., \& Zakariya, N. (2008). Measuring the Relative Risk of Impairment of Auditor Independence Using Dominance Analysis: Evidence from Malaysia. ICFAI Journal of Audit Practice, 5(4), $7-21$.

Law, P. (2010). The influence of the types of NAS provisions and gifts hospitality on auditor independence. International Journal of Accounting and Information Management, 18(2), 105-117. http://dx.doi.org/ $10.1108 / 18347641011048101$

Lennox, C. (2005). Audit quality and executive officers' affiliations with CPA firms. Journal of Accounting and Economics, 39(2), 201-231. http://dx.doi.org/10.1016/j.jacceco.2003.12.002

Lim, C. Y., \& Tan, H. T. (2010). Does Auditor Tenure Improve Audit Quality? Moderating Effects of Industry Specialization and Fee Dependence. Contemporary Accounting Research, 27(3), 923-957. http://dx.doi.org/ 10.1111/j.1911-3846.2010.01031.x

Lindblom, C. K. (1994, June). The implications of organizational legitimacy for corporate social performance and disclosure. In Critical perspectives on accounting conference, New York.

Lowe, D. J., \& Pany, K. (1996). An Examination of The Effects of Type of Engagement, Materiality And Structure On CPA Consulting. Accounting Horizons, 10(4), 32-51.

Lowe, D. J., Geiger, M. A., \& Pany, K. (1999). The effects of internal audit outsourcing on perceived external auditor independence. Auditing: A Journal of Practice \& Theory, 18(s-1), 7-26. http://dx.doi.org/10.2308 /aud.1999.18.s-1.7

McGrath, S., Siegel, A., Dunfee, T. W., Glazer, A. S., \& Jaenicke, H. R. (2001). A framework for auditor independence. Journal of Accountancy, 191(1), 39-42.

Menon, K., \& Williams, D. D. (2004). Former audit partners and abnormal accruals. The Accounting Review, 79(4), 1095-1118. http://dx.doi.org/10.2308/accr.2004.79.4.1095

Meyer, M. J., Rigsby, J. T., \& Boone, J. (2006). The impact of auditor-client relationships on the reversal of first-time audit qualifications. Managerial Auditing Journal, 22(1), 53-79. http://dx.doi.org/10.1108/02686 900710715648

Muhamad-Sori, Z., \& Mohamad, S. (2007). Potential Employment and Auditor Independence. Retrieved from http://ssrn.com/abstract=1031098

Muhamad-Sori, Z., Karbhari, Y., \& Mohamad, S. (2010). Commercialization of Accounting Profession: The Case of Non-audit Services. International Journal of Economics and Management, 4(2), 212-242.

Nelson, M. W. (2009). A model and literature review of professional skepticism in auditing. Auditing: A Journal of Practice \& Theory, 28(2), 1-34. http://dx.doi.org/10.2308/aud.2009.28.2.1

Okike, E. N. (2007). Corporate governance in Nigeria: The status quo. Corporate Governance: An International Review, 15(2), 173-193. http://dx.doi.org/10.1111/j.1467-8683.2007.00553.x

Olatunde, J., \& Lauwo, S. (2010). The Role of Auditors in Nigerian Banking Crisis. Acountancy Business and the Public Interest, 9, 159-204.

Owen, J. (2003). Report of the HIH Royal Commission. Commonwealth of Australia, Canberra.

Pany, K., \& Reckers, P. M. (1980). The effect of gifts, discounts, and client size on perceived auditor independence. Accounting Review, 50-61.

Pany, K., \& Reckers, P. M. (1983). Auditor independence and non-audit services: Director Views and their policy implications. Journal of Accounting and Public Policy, 2(1), 43-62. http://dx.doi.org/10.1016/0278-4254 (83)90018-2

Parasuraman, A., Zeithaml, V. A., \& Berry, L. L. (1985). A conceptual model of service quality and its implications for future research. Journal of marketing, 49(4). http://dx.doi.org/10.2307/1251430

Parlin, C. J., \& Bartlett, R. W. (1994). Prior employment effects and independence in fact. Business \& Professional Ethics Journal, 185-202. http://dx.doi.org/10.5840/bpej1994131/27

Pfeffer, J., \& Salancik, G. R. (2003). The external control of organizations: A resource dependence perspective. 
Stanford University Press.

Ponemon, L. A. (1995). The objectivity of accountants' litigation support judgments. Accounting Review, 467-488.

Power, M. K. (2003). Auditing and the production of legitimacy. Accounting, Organizations and Society, 28(4), 379-394. http://dx.doi.org/10.1016/S0361-3682(01)00047-2

Quick, R., \& Warming-Rasmussen, B. (2009). Auditor independence and the provision of non-audit services: Perceptions by German investors. International journal of auditing, 13(2), 141-162. http://dx.doi.org/10. 1111/j.1099-1123.2009.00397.x

Sharma, V. D., Sharma, D. S., \& Ananthanarayanan, U. (2011). Client importance and earnings management: The moderating role of audit committees. Auditing: A Journal of Practice \& Theory, 30(3), 125-156. http://dx.doi.org/10.2308/ajpt-10111

Shaub, M. K. (2004). Trust as a threat to independence: Emotional trust, auditor-client interdependence, and their impact on professional skepticism. Research on Professional Responsibility and Ethics in Accounting, 9, 169-188. http://dx.doi.org/10.1016/S1574-0765(04)09008-9

Shockley, R. A. (1981). Perceptions of auditors' independence: An empirical analysis. Accounting Review, 785-800.

Srivastava, R. P., Mock, T. J., \& Turner, J. L. (2009). Bayesian and belief-functions formulas for auditor independence risk assessment. International Journal of Auditing, 13(3), 163-183. http://dx.doi.org/10.1111/ j.1099-1123.2009.00384.x

Suchman, M. C. (1995). Managing legitimacy: Strategic and institutional approaches. Academy of management review, 20(3), 571-610.

Swanger, S. L., \& Chewning, Jr. E. G. (2001). The effect of internal audit outsourcing on financial analysts' perceptions of external auditor independence. Auditing: A Journal of Practice \& Theory, 20(2), 115-129. http://dx.doi.org/10.2308/aud.2001.20.2.115

Tribunella, T. J., \& Tribunella, H. R. (2011). The effect of auditor independence on international capital markets for e-commerce firms. Journal of Business \& Economics Research (JBER), 1(2), 49-60.

Trompeter, G. (1994). The effect of partner compensation schemes and generally accepted accounting principles on audit partner judgment. Auditing, 13, 56-68.

\section{Copyrights}

Copyright for this article is retained by the author(s), with first publication rights granted to the journal.

This is an open-access article distributed under the terms and conditions of the Creative Commons Attribution license (http://creativecommons.org/licenses/by/3.0/). 